\title{
Fødsler i førti år
}

\author{
Rolv T. Lie og Petter Kristensen
}

\begin{abstract}
Fødsel er et grunnleggende positivt uttrykk for livskraft og ny begynnelse. I vårt språk brukes fødsel som synonym for tilblivelse i mange sammenhenger. Men uttrykket følges ofte av en liten skygge av smerte eller belastning. Dette nummeret markerer at Medisinsk fødselsregister har registrert alle fødsler i Norge i førti år og hva dette har avfødt av viktig forskning og kunnskap. Nummeret markerer også at Lorentz Irgens går av som mangeårig leder ved registeret.
\end{abstract}

Det er noe ufattelig ved det at registeret har samlet betydningsfull informasjon om livstegn, livskraft, om dramatikk, om smerte og av og til om sorgfulle hendelser fra over 2 millioner fødsler. Denne virkeligheten kjenner vi angår svært mange, også oss som arbeider med registeret. Når denne enorme tyngden av informasjon om viktige hendelser i mange menneskers liv omsettes til tall, blir det en utfordring å formidle sammenhengen mellom tallene og den virkeligheten disse tallene er uttrykk for.

En rekke av bidragene i dette festskriftet forsøker å sette forskningsaktivitet og registerbruk inn i en samfunnssammenheng der betydningen av registeret for vanlige folk vektlegges. Dette nummeret kan på mange måter sees som et slags regnskap for hva registeret har vært brukt til, selv om mye av aktiviteten ved registeret knapt er nevnt. Men samtidig peker mange av bidragene på nye muligheter eller muligheter som ennå ikke har vært brukt fullt ut. Det er viktig for et livskraftig register. Enkelte av bidragene påpeker problemer eller utfordringer ved dataene. Det ligger i forskningens natur å engasjere seg for å forstå dataene best mulig, å arbeide for at dataene holder høy kvalitet og for å unngå at analyse av dataene forer til gale konklusjoner.

Historien om registerets tilblivelse er i seg selv spennende og en dramatisk påminnelse om nødvendigheten av et oppegående register. Thalidomidkatastrofen som førte til registerets opprettelse berøres av Geir Stene-Larsen i hans artikkel. Verden over ble tusener av barn på sekstitallet rammet av alvorlige lemmedefekter etter at deres mødre hadde brukt medikamentet Thalidomid under svangerskapet. Det at en ytre påvirkning kan gi slike dramatiske skader er fortsatt en viktig begrunnelse for registeret.

Registerets tidlige historie, der kjente personer som Gro Harlem Brundtland og Karl Evang spilte en rolle, fortelles i Lorentz Irgens' bidrag til dette nummeret. Det er en spennende historie om hvordan Tor Bjerkedal brakte registeret til Bergen, hvor det er blitt værende siden i det som er blitt det største registerepidemiologiske fagmiljøet utenfor Oslo. Vi skal komme tilbake til Lorentz Irgens sin rolle i denne sammenhengen.

Bidragene $\mathrm{i}$ dette nummeret er blitt delt inn $\mathrm{i}$ tre tematiske områder. Vi har valgt å samle en rekke kommentarartikler som setter registerets virksomhet inn $\mathrm{i}$ en større sammenheng i et første tematisk område. Geir Stene-Larsen som databehandlingsansvarlig gir en kommentar til registerets betydning for norsk folkehelse. Camilla Stoltenberg beskriver hvilke nye muligheter for forskning og overvåkning som ligger i det nye pasientregisteret, blant annet gjennom kobling med Medisinsk fødselsregister. Georg Apenes diskuterer personvern knyttet til bruk av pasientinformasjon og europeisk (og egen) tenkning på dette området. Allen Wilcox skriver om hvordan Medisinsk fødselsregister vurderes internasjonalt. Per Magnus gir en statusbeskrivelse for Den norske mor-og-barnstudien som også gir en rekke nye forskningsmuligheter og som også i stor grad benytter data fra Medisinsk fødselsregister. Steinar Tretli og medarbeidere ved Kreftregisteret, som er det andre store medisinske registermiljøet i Norge, gjennomgår forskning som har benyttet kobling av de to registrene og fremtidige muligheter for slik forskning. Sist men ikke minst forteller Per Bergsjø om hvordan et medisinsk fødselsregister kan bidra $i$ et utviklingsland.

I det andre tematiske området følger en rekke artikler som gir oversikt over mer spesifikk forskningsaktivitet ved registeret. Det er to spesielle eksempler i registerets historie på at registeret har hatt direkte betydning for tiltak for å bedre folkehelsen. Det ene er i avdekkingen av årsakene til krybbedødsepidemien på slutten av åttitallet. Denne spennende historien om hvordan endrede anbefalinger om liggestilling for nyfødte redder vel 100 barn i året fortelles av Nina Øyen. Det andre eksempelet er oppdagelsen av at Bvitaminet folat forebygger medfødte misdannelser, særlig nevralrørsmisdannelser; Stein Emil Vollset og medarbeidere gir en oppdatert oversikt. Tre andre artikler gjennomgår bruken av registeret i studier av yrkesforhold (Ågot Irgens og medarbeidere), studier av årsaker til medfødte misdannelser (Rolv T. Lie) og studier av langtidseffekter av fødselsutfall (Petter Kristensen). Leiv Bakketeig har skrevet en oversikt over studier av familiær gjentagelse hvor han særlig går inn på pionerstudier han selv gjennomførte allerede på 1970-tallet.

Det siste tematiske området består av artikler som bidrar med ny informasjon basert på registerets data. De to første tar for seg kvaliteten av registeret. Dette er svært viktig arbeid fordi det sikrer verdien av de data- 
ene som møysommelig er samlet inn og bearbeidet. Tor Bjerkedal, som vi også skal komme tilbake til, har sammen med Petter Kristensen sammenholdt fødselsregisterets diagnoser med diagnoser fra NAV-registrene. De viser at så mye som $70 \%$ av barn som lever opp med en Downs syndromdiagnose er registrert $\mathrm{i}$ Medisinsk fødselsregister. Lars Christian Stene og medarbeidere bidrar med ny kunnskap om registerets registrering av diabetesdiagnoser. Rolv Skjærven og Kari Klungsøyr Melve viser hvordan registeret kan brukes til å beskrive hvordan fødselsutfall påvirker sjansen for at en kvinne blir gravid igjen senere og hvordan slik selektiv fertilitet må taes hensyn til i epidemiologiske studier. Dag Moster og Trond Markestad viser at registeret kan brukes til å studere viktige pediatriske tilstander, og Per Bergsjø og Svein Rasmussen viser tilsvarende for obstetriske forhold.

Samlet sett mønstrer dette nummeret en rekke forfattere som har vært sentrale aktører rundt medisinsk fødselsregister gjennom førti år. Interessen for og kjærligheten til dette registeret er livslang for mange av disse forfatterne.

Dette nummeret feirer førti år for Medisinsk fødselsregister. I en slik sammenheng er det naturlig å fokusere på registerets lederskap. Tor Bjerkedal var registerets første leder og bygde opp registeret og etablerte det ved Institutt for hygiene og sosialmedisin i Bergen. Bjerkedals visjon om at instituttet skulle ta på seg den samfunnsoppgaven det var å lede Medisinsk fødselsregister kan ha vært medvirkende til at det fikk en så fast forankring i Bergensmiljøet. Fra 1976, etter at Bjerkedal flyttet fra Bergen og senere fikk et professorat ved Universitetet i Oslo, var det en overgangsperiode på flere år med et lederskap som i praksis var delt før Lorentz Irgens formelt ble leder for registeret $\mathrm{i}$ 1986. Ved registerets førtiårsfeiring er en epoke over ved at han takker av som leder. Vi ønsker derfor at dette nummeret skal markere Lorentz Irgens' avgang på en spesiell måte og inviterte ham til å skrive en nokså personlig beretning om registeret og hans eget forhold til det. Det er ingen tvil om at både Tor Bjerkedal og Lorentz Irgens gjennom en årrekke har vært betydelige personer innenfor norsk epidemiologi. Irgens gir også et interessant innblikk $\mathrm{i}$ det nære forholdet mellom de to ved at han gir Bjerkedal mye av æren for at han selv valgte å satse på epidemiologi som fag.

Lorentz Irgens har identifisert seg sterkt med registeret og arbeidet hardt for at Medisinsk fødselsregister ikke bare skulle være en samling med data men også ha et institusjonspreg. Det har han på mange måter klart, også etter at registeret som ett av flere sentrale helseregistre fra 2002 ble organisert med Nasjonalt folkehelseinstitutt som databehandlingsansvarlig. Under Irgens' ledelse har fødselsregisteret også vokst betydelig og inneholder i dag mange nye aktiviteter som han selv redegjør for i sin artikkel. Han har også hatt en klar visjon om at registeret skal tjene både forskning og forvaltning.

Det er ikke mulig å skrive om Lorentz Irgens uten å komme inn på hans tydelige karakter. Samtidig som Irgens nok har blitt betraktet som en sterk og klassisk ledertype har han også gjennom samarbeid involvert registeret i en rekke samarbeidsprosjekt og nettverk. Innad har han kombinert en markant lederprofil med omsorg for de ansatte. Dette er egenskaper ved ham som vi må anta har hatt betydning for registermiljøets og hans egen betydelige produktivitet og for stabiliteten av personalet ved registeret.

Det er derfor grunn til å gratulere ham ved hans avgang. Vi har ingen tro på at han vil bli uvirksom med det første. Hans forgjenger Tor Bjerkedal er fortsatt meget produktiv som forsker. Lorentz Irgens beskriver selv at hans faglige utgangspunkt var interesse for historie. Kanskje vil han nå med sin spesielle kompetanse få bedre anledning til å dyrke den interessen igjen.

Det ligger også spennende muligheter for Medisinsk fødselsregister i det at en leder går av. Mulighetene er til stede for at det kan fødes noe nytt. Et avansert epidemiologisk register skal utvikles videre inn $i$ en ny tid. 